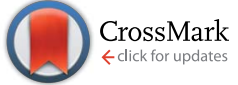

Cite this: J. Mater. Chem. A, 2016, 4, 12170

Received 1st May 2016

Accepted 11th July 2016

DOI: $10.1039 / c 6 t a 03623 f$

www.rsc.org/MaterialsA

\section{Fluoride substitution in sodium hydride for thermal energy storage applications $\dagger$}

\author{
T. D. Humphries, ${ }^{\star}$ D. A. Sheppard, M. R. Rowles, M. V. Sofianos and C. E. Buckley
}

The solid-state solutions of $\mathrm{NaH}_{x} \mathrm{~F}_{1-x}(x=1,0.95,0.85,0.5)$ have been investigated to determine their potential for thermal energy applications. Thermal analyses of these materials have determined that an increase in fluorine content increases the temperature of hydrogen release, with a maximum rate of desorption at $443{ }^{\circ} \mathrm{C}$ for $\mathrm{NaH}_{0.5} \mathrm{~F}_{0.5}$ compared to $408{ }^{\circ} \mathrm{C}$ for pure $\mathrm{NaH}$, while pressure-compositionisotherm measurements have established a $\Delta H_{\text {des }}$ of $106 \pm 5 \mathrm{~kJ} \mathrm{~mol}^{-1} \mathrm{H}_{2}$ and $\Delta S_{\text {des }}$ of $143 \pm 5 \mathrm{~J} \mathrm{~K}^{-1}$ $\mathrm{mol}^{-1} \mathrm{H}_{2}$, compared to $117 \mathrm{~kJ} \mathrm{~mol}^{-1} \mathrm{H}_{2}$ and $167 \mathrm{~J} \mathrm{~K}^{-1} \mathrm{~mol}^{-1} \mathrm{H}_{2}$, respectively, for pure $\mathrm{NaH}$. While fluorine substitution actually leads to a decrease in the stability (enthalpy) compared to pure $\mathrm{NaH}$, it has a larger depressing effect on the entropy that leads to reduced hydrogen equilibrium pressures. In situ powder X-ray diffraction studies have ascertained that decomposition occurs via enrichment of fluorine in the $\mathrm{NaH}_{x} \mathrm{~F}_{1-x}$ composites while, unlike pure $\mathrm{NaH}$, rehydrogenation is easily achievable under mild pressures. Further, cycling studies have proven that the material is stable over at least seven hydrogen sorption cycles, with only a slight decrease in capacity while operating between 470 and $520{ }^{\circ} \mathrm{C}$. Theoretically, these materials may operate between 470 and $775{ }^{\circ} \mathrm{C}$ and, as such, show great potential as thermal energy storage materials for concentrating solar thermal power applications.

\section{Introduction}

Currently, the population of the world is increasing by 80 million people per year, which, along with technological growth, puts a tremendous strain on global energy production. ${ }^{1}$ Even if fossil fuel reserves were not dwindling, alternative energy sources are unquestionably required and many renewable energy projects are underway globally. Some of the largest projects involve the construction of concentrating solar-thermal power (CSP) stations that harvest the sun's energy in the form of heat that is used directly to produce electricity. ${ }^{2}$ In order to produce electricity at night time or during periods of low sunlight, thermal energy storage has been implemented at a number of these stations including a state-of-the-art $110 \mathrm{MW}$ plant in Nevada called the Crescent Dunes Solar Energy Plant. ${ }^{2}$ Using molten $\mathrm{NaNO}_{3} / \mathrm{KNO}_{3}$ salts, this station has the capacity to store $10 \mathrm{~h}$ of thermal energy at full load for electricity production.

Molten salts are the first generation of thermal energy storage materials used for CSP and, as such have their drawbacks including low heat storage capacity, large volumes, high

Department of Physics and Astronomy, Fuels and Energy Technology Institute, Curtin University, GPO Box U1987, Perth,WA 6845, Australia.E-mail: terry_humphries81@ hotmail.com

$\dagger$ Electronic supplementary information (ESI) available: XRD analysis of annealed $\mathrm{NaH}_{x} \mathrm{~F}_{1-x}$ materials; van't Hoff plots of $\mathrm{NaH}_{0.5} \mathrm{~F}_{0.5}$; variation of $\Delta H$ and $\Delta S$ as function of hydrogen desorption; composition of $\mathrm{NaH}_{0.5} \mathrm{~F}_{0.5}$ as a function of temperature measured by in situ XRD. See DOI: 10.1039/c6ta03623f costs, and an operating temperature that is limited to $565^{\circ} \mathrm{C} .{ }^{3}$ Metal hydrides are thermochemical heat storage materials and have 5-30 times the energy density of molten salts and have the potential to reduce the heat storage costs of next generation CSP. ${ }^{4,5}$ Recent discussion of this topic has identified a range of high temperature metal hydrides that have the potential to operate at temperatures far exceeding those of molten salts $\left(\sim 565{ }^{\circ} \mathrm{C}\right)$, supercritical- $\mathrm{CO}_{2}\left(650^{\circ} \mathrm{C}\right)$, and also the next generation of power tower technology $\left(650-800{ }^{\circ} \mathrm{C}\right),{ }^{6,7}$ although reversibility and cost are the key issues to solve. ${ }^{8-13}$

Fluorine stabilised metal hydrides have recently been proposed for high-temperature thermal storage. ${ }^{3}$ The comparable ionic size of the hydride and fluoride ions and the structural similarity of their compounds were recognised before the $1960 \mathrm{~s},{ }^{14}$ with recent studies determining that fluorine substitution leads to increased thermal stability while also reducing system costs. For instance, $\mathrm{NaMgH}_{2} \mathrm{~F}$ releases hydrogen at $545^{\circ} \mathrm{C}$ at a pressure of 10 bar compared to $493{ }^{\circ} \mathrm{C}$ for $\mathrm{NaMgH}_{3} \cdot{ }^{15,16}$ Though $\mathrm{NaMgH}_{2} \mathrm{~F}$ has a lower heat storage capacity compared to other Mg-based hydrides, its higher operating temperature and thermal stability results in a lower system installed cost. ${ }^{8,15,17}$

It was originally theorised that a solid solution between $\mathrm{NaH}$ and NaF would be unlikely to form due to the relatively large difference in lattice constant and Born-Haber lattice energies between $\mathrm{NaH}$ and NaF. ${ }^{14}$ However, recent $a b$ initio calculations and Calphad modelling have predicted that the enthalpy of mixing between $\mathrm{NaH}$ and $\mathrm{NaF}$ is slightly negative $\left(\sim 2 \mathrm{~kJ} \mathrm{~mol}^{-1}\right)$ and a single solid solution is obtainable. ${ }^{18}$ At the same time, the 
authors of ref. 18 predicted that fluorine substitution will increase the equilibrium decomposition temperature. In this study, $\mathrm{NaH}$ has been mixed with NaF to successfully form solid solutions of $\mathrm{NaH}_{x} \mathrm{~F}_{1-x}$ and their thermal decomposition, thermodynamics, and reversibility determined by PCI (pressurecomposition-isotherm), TPD (temperature programmed desorption) and XRD (powder X-ray diffraction) analysis. These results have been directly compared to $\mathrm{NaH}$, a material that to date has negligible reversibility, despite having superior thermal stability compared to other binary hydrides for CSP applications. ${ }^{9}$

\section{Experimental}

All handling of chemicals and sealable milling canisters was undertaken in an argon-atmosphere Mbraun Unilab glovebox in order to minimise oxygen $\left(\mathrm{O}_{2}<1 \mathrm{ppm}\right)$ and water $\left(\mathrm{H}_{2} \mathrm{O}<1 \mathrm{ppm}\right)$ contamination. $\mathrm{NaH}$ (95\%, Sigma-Aldrich) and $\mathrm{NaF}$ (99.99\%, Sigma-Aldrich) were milled at various ratios (Table 1) inside an Across International Planetary Ball Mill (PQ-N04) employing tempered steel vials and balls in an Ar atmosphere. A ball-topowder mass ratio of $30: 1$ was employed, with a total milling time of $3 \mathrm{~h}$ at a speed of $400 \mathrm{rpm}$. Following milling, the samples were generally annealed under a $\mathrm{H}_{2}$ pressure of $40 \mathrm{bar}$ at $460{ }^{\circ} \mathrm{C}$ for 6 days.

Ex situ powder X-ray diffraction (XRD) was performed using a Bruker D8 Advance diffractometer ( $\mathrm{Cu} \mathrm{K} \alpha$ radiation) utilising XRD sample holders covered with a poly(methylmethacrylate) (PMMA) airtight bubble to prevent oxygen/moisture contamination during data collection. The PMMA bubble results in a broad hump in XRD patterns centred at $\sim 20^{\circ} 2 \theta$. The powder was mixed with $10 \mathrm{wt} \% \mathrm{Si}$ (-325 mesh, 99\%, Aldrich) as an internal reference to accurately determine sample displacement errors. Data was acquired over a $2 \theta$ range of $20-80^{\circ}$, with step size of $0.02^{\circ}$ and count time of $1 \mathrm{~s}$ per step. In situ synchrotron powder X-ray diffraction (SR-XRD) was performed at the Australian Synchrotron in Melbourne, Australia. ${ }^{19} \mathrm{NaH} / \mathrm{NaF}$ powder was loaded in a quartz capillary (outer diameter $0.7 \mathrm{~mm}$, wall thickness $0.01 \mathrm{~mm}$ ) and mounted in a sample holder with Swagelok tube fittings while inside a glove box filled with purified argon $\left(<1\right.$ ppm $\mathrm{O}_{2}$ and $\left.\mathrm{H}_{2} \mathrm{O}\right)$. The sample holder was then connected to a $\mathrm{H}_{2}$ gas filling/vacuum manifold, and the capillary heated with a hot air blower with a heating rate of $5{ }^{\circ} \mathrm{C}$ $\min ^{-1}$, under a 1 bar $\mathrm{H}_{2}$ atmosphere. One-dimensional SR-XRD patterns (monochromatic X-rays with $\lambda=0.824890 \AA$ A) were continuously collected using a Mythen microstrip detector ${ }^{20}$ with an exposure time of $27 \mathrm{~s}$. The capillary was oscillated $120^{\circ}$ during exposure to improve the powder averaging. Diffraction patterns were quantitatively analysed with the Rietveld method $^{21}$ using TOPAS (Bruker-AXS). The low atomic number of hydrogen usually presents difficulties for Rietveld refinement of hydrogen containing phases. However, the occupancy of hydrogen and fluorine can be readily obtained for $\mathrm{NaH}_{x} \mathrm{~F}_{1-x}$ solid solutions due to dramatic changes in diffracted peak intensities that occurs upon fluorine substitution for hydrogen (Fig. S1†).

The composition of $\mathrm{NaH}_{x} \mathrm{~F}_{1-x}$ materials after hydrogen sorption experiments were estimated by comparing the lattice parameters determined from lab-based XRD to the lattice parameters and composition determined from SR-XRD. For the room temperature measurements, a linear fit of the lattice parameters of the annealed $\mathrm{NaH}_{x} \mathrm{~F}_{1-x}$ powders (Table 1) against $\mathrm{H}$ : $\mathrm{F}$ ratios was generated. Above room temperature compositions were determined by firstly constructing a linear fit of the lattice parameters during thermal expansion of each annealed material from room temperature to $430{ }^{\circ} \mathrm{C}$ collected during in situ SR-XRD measurements. Quadratic expressions were then constructed from the lattice parameters against $\mathrm{H}$ : $\mathrm{F}$ ratios over the whole temperature range. This allowed the determination of $\mathrm{NaH}_{x} \mathrm{~F}_{1-x}$ composition by SR-XRD from the in situ SR-XRD data.

The hydrogen sorption properties were examined by measuring Pressure-Composition-Isotherms (PCI) between 450 ${ }^{\circ} \mathrm{C}$ and $520{ }^{\circ} \mathrm{C}$ with a computer controlled Sieverts/volumetric apparatus previously described. ${ }^{22}$ The digital pressure transducer (Rosemount 3051S) has a precision and accuracy of 14 mbar, whilst room temperature measurements were recorded using a 4-wire platinum resistance temperature detector (RTD). The sample temperature was monitored using a K-type thermocouple that was calibrated by the manufacturer to be accurate within $0.1{ }^{\circ} \mathrm{C}$ at $419{ }^{\circ} \mathrm{C}$. Above $\sim 420{ }^{\circ} \mathrm{C}$, the permeation of hydrogen directly through the walls of the stainless steel sample cell becomes an issue and the measured hydrogen content at each PCI data point has to be corrected for this loss. A full explanation of the correction method has previously been explained in detail. ${ }^{15}$

Hydrogen sorption cycling studies were carried out utilising the same apparatus as for the PCI experiments. In order to inhibit $\mathrm{Na}$ evaporation during the experiment, the $\mathrm{NaH}_{x} \mathrm{~F}_{1-x}$ sample was loaded inside an Fe tube (wall thickness of 0.025 $\mathrm{cm}$, inner diameter of $0.45 \mathrm{~cm}) .{ }^{23,24}$ The bottom of the Fe tube

Table 1 Structural and thermal properties of $\mathrm{NaH}_{x} \mathrm{~F}_{1-x}$ mixtures. Esd's of lattice parameters and $\mathrm{H}$ occupancies of the $4 b$ site are in parentheses

\begin{tabular}{llllllll}
\hline $\begin{array}{l}\text { NaH/NaF } \\
\text { molar ratio }\end{array}$ & $\begin{array}{l}\text { NaH/NaF } \\
\text { weight ratio }\end{array}$ & $\begin{array}{l}\text { Lattice } \\
\text { parameter }(\AA)\end{array}$ & H occupancy & $\begin{array}{l}\text { Max } \mathrm{H}_{2} \\
\text { release }\left({ }^{\circ} \mathrm{C}\right)\end{array}$ & $\begin{array}{l}\text { Desorbed } \mathrm{H}_{2} \\
\text { (theoretical) }(\mathrm{wt} \%)\end{array}$ & $\begin{array}{l}\text { Reabsorbed } \\
\mathrm{H}_{2}(\text { wt } \%)\end{array}$ & $\begin{array}{l}\text { Fraction of desorbed } \\
\mathrm{H}_{2} \text { reabsorbed }(\%)\end{array}$ \\
\hline $100: 0$ & $100: 0$ & $4.8814(2)$ & 1 & 408 & $3.53(4.20)$ & 0.2 & 5.7 \\
$95: 5$ & $92: 8$ & $4.8642(2)$ & $0.908(1)$ & 413 & $3.24(3.85)$ & 0.32 & 9.9 \\
$85: 15$ & $76: 24$ & $4.8305(2)$ & $0.7904(8)$ & 417 & $2.43(3.20)$ & 0.36 & 14.8 \\
$70: 30$ & $57: 43$ & $4.7856(4)$ & $0.595(1)$ & 430 & $1.82(2.40)$ & 0.88 & 48.4 \\
$50: 50$ & $36: 64$ & $4.7407(2)$ & $0.449(2)$ & 443 & $1.11(1.53)$ & 0.70 & 63.1 \\
$0: 100$ & $0: 100$ & $4.63419(3)$ & 0 & - & - & - & -
\end{tabular}


was crimped tube placed inside the reactor vessel. To allow the sample to fully absorb and desorb hydrogen during cycling, 3 bar $\mathrm{H}_{2}$ was applied to the vessel before cycling between $520{ }^{\circ} \mathrm{C}$ $\left(P_{\text {eq }}\left(\mathrm{H}_{2}\right) \sim 3.1\right.$ bar $)$ and $472{ }^{\circ} \mathrm{C}\left(P_{\text {eq }}\left(\mathrm{H}_{2}\right) \sim 1.1\right.$ bar $)$ for $6 \mathrm{~h}$ per step for a total of 7 repetitions.

Temperature Programmed Desorption (TPD) experiments were carried out using an identical apparatus to those described in the PCI measurements, although the experimental conditions were altered. Prior to heating the samples in a closed system, the vessel was kept in vacuo. Samples were heated from room temperature to $550{ }^{\circ} \mathrm{C}$ at $2{ }^{\circ} \mathrm{C} \mathrm{min}^{-1}$ followed by an isothermal stage for $40 \mathrm{~min}$. The vessel was then allowed to cool under its own thermal dissipation rate. The sample masses were chosen such that they each contained the same quantity of hydrogen.

\section{Results and discussion}

\section{Synthesis}

$\mathrm{NaH}$ and NaF powders were ball-milled in various ratios (Table 1) and annealed at $460{ }^{\circ} \mathrm{C}$ for six days under 40 bar $\mathrm{H}_{2}$. The resultant powders were analysed by SR-XRD (Fig. 1a) and the data refined using the Rietveld method (Fig. S1 and Table S1 $\dagger$ ) indicating that neither starting materials were present (Table $\mathrm{S} 2 \dagger)$. $\mathrm{NaH}$ and $\mathrm{NaF}$ exist in the crystallographic space group $F m \overline{3} m$ with lattice parameters of $4.8814(2)$ and $4.63419(3) \AA$, respectively (after milling and annealing). The increase in lattice parameters between $\mathrm{NaF}$ to $\mathrm{NaH}$ is due to the increase of bond length between the $\mathrm{Na}$ and respective anion $(\mathrm{Na}-\mathrm{F}=2.308 \AA$, $\mathrm{Na}-\mathrm{H}=2.445 \AA$ A). ${ }^{25,26}$ Consequently, each product consisted of a single phase, which also indexed to the space group $F m \overline{3} m$, with the refined lattice parameters residing between those of the pure alkali metal salts (Table 1). As expected, a solid-solution has been produced in the form of $\mathrm{NaH}_{x} \mathrm{~F}_{1-x}$ where the $\mathrm{H}$ and $\mathrm{F}$ are randomly distributed on the $4 b$ site. The hydrogen positions and occupancies within metal hydrides are usually difficult to determine via XRD. However, partial substitution of hydrogen for fluorine results in strong changes in peak intensity that can be used to elucidate the hydrogen occupancy (Fig. S1 and
Table S1†). Plotting the lattice parameters and $\mathrm{H}$ occupancy against the initial $\mathrm{NaH} / \mathrm{NaF}$ fractions exhibits a linear correlation (Fig. 1b) that obeys Vegard's law. ${ }^{27}$ As such, lattice parameters (LP) increase directly with $\mathrm{NaH}$ ratio providing us with eqn (1), which can subsequently aid with deducing the composition of materials after hydrogen sorption cycles.

$$
\mathrm{LP}=0.0024 \times(\mathrm{NaH} \text { mole fraction })+4.6277
$$

It is noted that this correlation could be slightly improved by the use of a quadratic function, but a linear correlation allows for a simplistic approach to determine the approximate composition of the solid solutions. Overall the $R^{2}$ value for the linear fit was 0.998 , while the $R^{2}$ value for the polynomial fit was 0.9998. On a side note, the refined $\mathrm{H}$ occupancies appear to be consistently lower than the as-milled $\mathrm{NaH} / \mathrm{NaF}$ fractions. This could be attributed to the greater X-ray scattering of F compared to $\mathrm{H}$. This scenario may have also arisen from the difference in purity between the $\mathrm{NaH}(95 \%)$ and $\mathrm{NaF}$ (>99.99\%) starting materials. Even though the purchased $\mathrm{NaH}$ was labelled as $95 \%$ pure, Rietveld refinement of a ball milled and annealed sample (in order to replicate the method used to synthesise the $\mathrm{NaH}_{x}$ $\mathrm{F}_{1-x}$ mixtures) indicated a presence of $12 \mathrm{wt} \% \mathrm{NaOH}$ (Table $\mathrm{S} 2$ and Fig. $\mathrm{S} 1 \dagger)$. Therefore, the use of lattice parameters to estimate the $\mathrm{H} / \mathrm{F}$ composition is more efficient than the refined $\mathrm{H}$ occupancies of the materials.

Annealing the samples under $\mathrm{a}_{2}$ atmosphere is essential to attain a solid-solution; merely milling the materials results in diffraction peaks for the $\mathrm{NaF}$ and $\mathrm{NaH}$ starting materials (Fig. S2 $\dagger$ ). Annealing was initially conducted on the as-milled $\mathrm{NaH}_{0.5} \mathrm{~F}_{0.5}$ at $300{ }^{\circ} \mathrm{C}$, under 30 bar $\mathrm{H}_{2}$ for three days, where a wide variety of $\mathrm{NaH}_{x} \mathrm{~F}_{1-x}$ compositions were observed including 7 wt $\%$ NaF, $40 \mathrm{wt} \% \mathrm{NaH}_{0.25} \mathrm{~F}_{0.75}$ and $54 \mathrm{wt} \%$ $\mathrm{NaH}_{0.57} \mathrm{~F}_{0.43}$ (Table $\mathrm{S} 3 \dagger$ ). $\mathrm{H}_{2}$ pressure is often used for annealing at these temperatures in order to avoid hydrogen desorption from $\mathrm{NaH}$.

Subsequent annealing at $460{ }^{\circ} \mathrm{C}$ for a total of six days resulted in a single phase when analysed by laboratory based
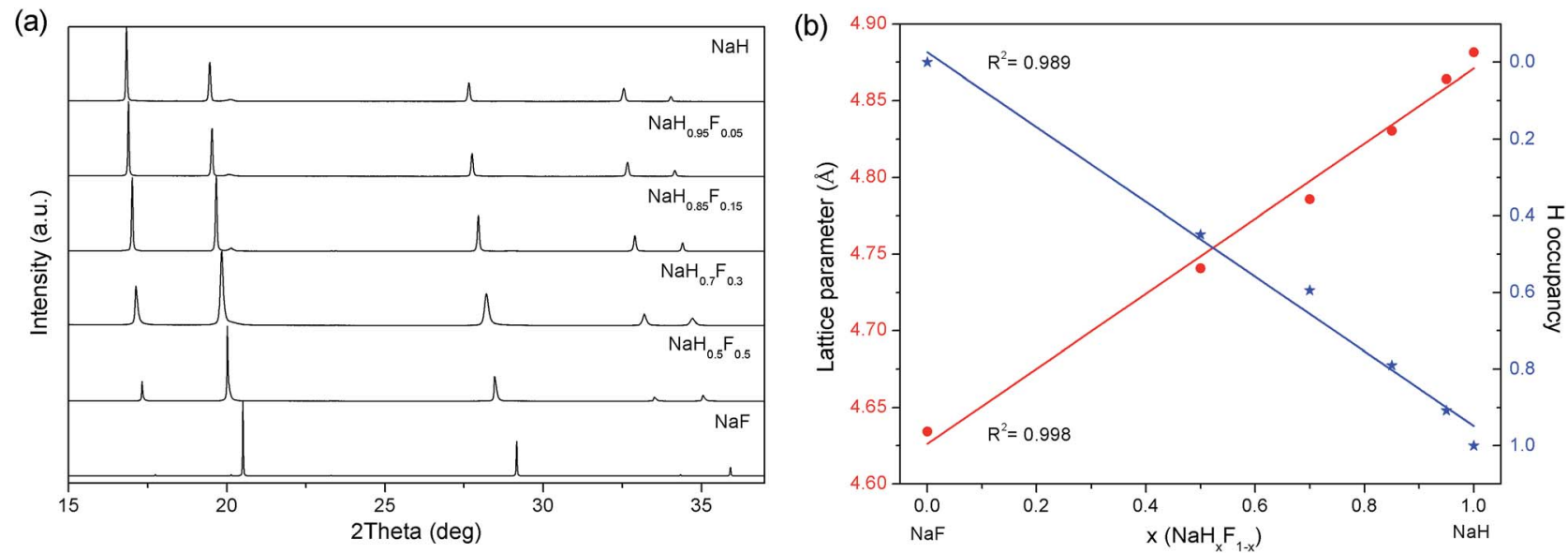

Fig. 1 SR-XRD patterns (a) and refined lattice parameters and $\mathrm{H}$ occupancies (b) of $\mathrm{NaH}_{x} \mathrm{~F}_{1-x}$ mixtures. $\lambda=0.824890 \AA, T=27^{\circ} \mathrm{C}$. 
XRD. Further analysis of the sample (annealed for 6 days) by SRXRD showed asymmetric broadening of the diffraction peaks that indicates that the sample was not quite fully homogenous and that small proportions of higher F containing species were present (although not measureable by laboratory XRD analysis) (Fig. S3†). Further annealing of the sample under 1 bar $\mathrm{H}_{2}$ was inadvertently monitored by in situ SR-XRD, where one single phase was finally observed at $\sim 140{ }^{\circ} \mathrm{C}$ (Fig. 4a). To investigate this result, ex situ annealing was conducted on the as-milled material at $200{ }^{\circ} \mathrm{C}$, under 1 bar $\mathrm{H}_{2}$ or 1 bar $\mathrm{Ar}$ for $24 \mathrm{~h}$. It was assumed that excess $\mathrm{H}_{2}$ pressure may inhibit the reaction between $\mathrm{NaH}$ and $\mathrm{NaF}$, as observed previously with $\mathrm{NaBH}_{4}$ and $\mathrm{NaCl}$ mixtures. ${ }^{28}$ As such, after XRD, a reduction in solid-state solution production was achieved by employing milder annealing conditions, with $\sim 44$ wt $\%$ NaF being present under both reaction atmospheres (Fig. S2 and Table S3†). It is therefore understood that at $200{ }^{\circ} \mathrm{C}$ the reaction atmosphere does not affect the reaction outcome, although increased temperatures promote the formation of the solid-state solution. One explanation for the additional annealing that occurred during the in situ XRD is that the material has already been subjected to an annealing cycle and so much lower diffusion distances are required to produce a single-phase solid solution.

\section{Thermal desorption studies}

To ascertain the relative stabilities of the $\mathrm{NaH}_{x} \mathrm{~F}_{1-x}$ samples, TPD analysis was carried out. In conventional TPD experiments, the desorbed gases are measured by Mass Spectrometry or by acquiring the partial pressure as the gases are removed from the system under reduced pressure. ${ }^{29,30}$ In this experiment, the gases were desorbed into a closed system and the incremental pressure changes used to determine the rate of gas desorption (Fig. 2). A small enough quantity of material was used so as not to reach atmospheric pressure and hence limit the possibility of thermodynamic inhibition. The first notable aspect is that the theoretical $\mathrm{H}_{2}$ capacity for each $\mathrm{NaH}_{x} \mathrm{~F}_{1-x}$ composition was not obtained (Fig. 2a and Table 1). It is normal for the theoretical capacity not to be achieved due to impurities in the sample and $\mathrm{H}_{2}$ permeation through the vessel walls (even though a correction coefficient was implemented). ${ }^{16}$ The rate of $\mathrm{H}_{2}$ release dramatically decreases as the fraction of NaF increases, as does the onset temperature of $\mathrm{H}_{2}$ desorption. To accurately determine the temperature of the maximum rate of $\mathrm{H}_{2}$ release, the first derivative of the desorbed wt $\%$ was calculated (Fig. 2b and Table 1). It is clear that the addition of NaF considerably increases the temperature of desorption of $\mathrm{NaH} ; \mathrm{NaH}_{0.5} \mathrm{~F}_{0.5}$ has a maximum $\mathrm{H}_{2}$ release rate at $443{ }^{\circ} \mathrm{C}$, while $\mathrm{NaH}$ has a maximum at $408{ }^{\circ} \mathrm{C}$. In fact, the maximum release rate temperature increases linearly with increasing NaF. This is the desired effect, although for $\mathrm{NaH}_{0.5} \mathrm{~F}_{0.5}$, the hydrogen capacity is only $36 \%$ of pure $\mathrm{NaH}$ (Table 1 ). Further addition of NaF will ultimately decrease the $\mathrm{H}_{2}$ capacity to such an extent as to make it inadequate for thermal energy applications.

One interesting inference from the TPD data is that the addition of fluorine allows the $\mathrm{NaH}_{x} \mathrm{~F}_{1-x}$ systems to reabsorb $\mathrm{H}_{2}$. NaH is renowned for having negligible $\mathrm{H}_{2}$ reversibility even at increased pressures. ${ }^{8}$ The maximum pressure of desorbed gas obtained in these experiments was 0.86 bar for $\mathrm{NaH}$ while the $\mathrm{NaH}_{x} \mathrm{~F}_{1-x}$ systems never reached above 0.8 bar. At these pressures $\mathrm{H}_{2}$ was reabsorbed by the $\mathrm{NaH}_{x} \mathrm{~F}_{1-x}$ systems during cooling and the relative quantity increased with increasing $\mathrm{NaF}$ fraction (Fig. 2a and Table 1). $\mathrm{NaH}_{0.5} \mathrm{~F}_{0.5}$ reabsorbed $0.7 \mathrm{wt} \% \mathrm{H}_{2}$, which is $63 \%$ of the total quantity of $\mathrm{H}_{2}$ desorbed. Once the temperature decreased to $\sim 350{ }^{\circ} \mathrm{C}$ the absorption halted, presumably due to kinetic limitations, and so it is feasible that full reabsorption could be achieved provided the temperature is maintained above $\sim 350{ }^{\circ} \mathrm{C}$. The only factor inhibiting maximum $\mathrm{H}_{2}$ reabsorption is the loss of $\mathrm{Na}$ content during the experiment, as the high vapour pressure of molten sodium metal causes its distillation. ${ }^{\mathbf{2 3 2}}$ In fact, virtually no Na was observed by XRD in the remaining $\mathrm{NaH}_{0.5} \mathrm{~F}_{0.5}$ after the TPD measurement. In addition, the lattice parameter of $4.723 \AA$ for the $\mathrm{NaH}_{x} \mathrm{~F}_{1-x}$ phase suggests a composition of $\mathrm{NaH}_{0.4} \mathrm{~F}_{0.6}$ (using eqn (1)); a loss of $20 \mathrm{~mol} \%$ of $\mathrm{NaH}$. (a)

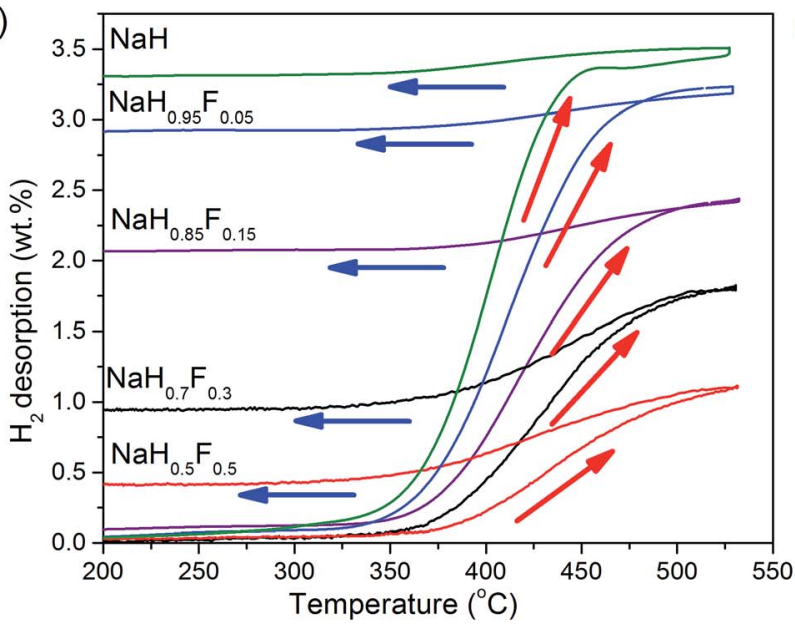

(b)

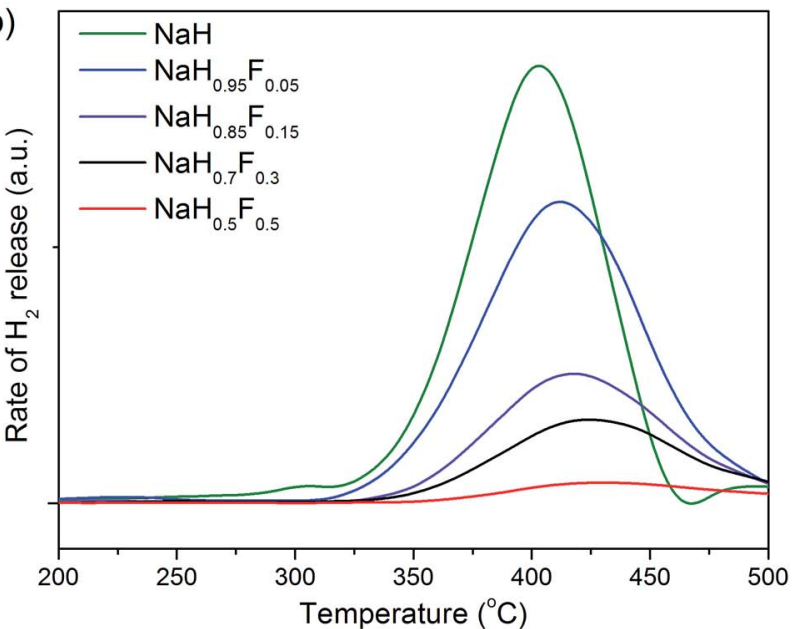

Fig. 2 TPD analysis of $\mathrm{NaH}_{x} \mathrm{~F}_{1-x}$ samples (heating rate $=2{ }^{\circ} \mathrm{C} \mathrm{min}^{-1}$ ). (a) $\mathrm{H}_{2}$ desorption during heating and cooling $(\rightarrow$ indicates direction of experimental data). (b) Rate of $\mathrm{H}_{2}$ desorption during heating. 
Hydrogen desorption PCI measurements were performed on $\mathrm{NaH}_{0.5} \mathrm{~F}_{0.5}$ between $450{ }^{\circ} \mathrm{C}$ and $520^{\circ} \mathrm{C}$ in order to determine the thermodynamics of hydrogen release (Fig. 3a). It is evident from the four curves that desorption occurs in a single step, although the sloping plateaux are consistent with the hydrogen existing as a randomly distributed solid-solution rather than a stoichiometric hydride phase. ${ }^{15}$ The lack of flat plateaux is a disadvantage from an engineering perspective where absorption and desorption of hydrogen at a constant equilibrium pressure is ideal. One major setback to sloping equilibrium pressures is that the operational pressures for which full reversibility is achievable become wider as lower pressures are required for full dehydrogenation while higher pressures are required for full hydrogenation. A lab-based work-around for this situation is to increase the volume of the reactor and extend the temperature differential between desorption and absorption. Upon scale up, engineering considerations will have to be made to avoid excessively large reactor volumes.

To determine the thermodynamics of hydrogen release, van't Hoff plots were constructed (Fig. $3 \mathrm{~b})$. The enthalpy $\left(\Delta H_{\text {des }}\right)$ and entropy $\left(\Delta S_{\text {des }}\right)$ were determined via two methods. The first, simply involved determining the pressure at $-0.55 \mathrm{wt} \%$ of $\mathrm{H}_{2}$ content. This gave $\Delta H_{\mathrm{des}}=106 \mathrm{~kJ} \mathrm{~mol}^{-1} \mathrm{H}_{2}$ and $\Delta S_{\mathrm{des}}=143 \mathrm{~J}$ $\mathrm{K}^{-1} \mathrm{~mol}^{-1} \mathrm{H}_{2}$ with an associated $R^{2}$ factor of 0.997 (Fig. 3b). The second method involved numerically fitting each PCI curve with a quadratic function (Fig. S4 $\dagger$ ) so that $\Delta H_{\text {des }}$ and $\Delta S_{\text {des }}$ could be determined over the whole range of compositions (Fig. S5 $\dagger$ ). The van't Hoff plots for hydrogen desorption values below $-0.9 \mathrm{wt} \%$ showed a poor fit and were not considered further. The poor fits are possibly due to small errors in the calculated leak rates that accumulate over the course of the desorption measurements that may compound at lower pressures. As a result, at $0.55 \mathrm{wt} \% \mathrm{H}_{2}, \Delta H_{\mathrm{des}}=109 \mathrm{~kJ} \mathrm{~mol}^{-1} \mathrm{H}_{2}$ and $\Delta S_{\mathrm{des}}=$ $147 \mathrm{~J} \mathrm{~K}^{-1} \mathrm{~mol}^{-1} \mathrm{H}_{2}$ with an associated $R^{2}$ factor of 0.989 for method 2. The inconsistency observed between the two methods is likely due to the numerical fitting of the data, although systematic errors can be attributed to fluctuations in temperature during the experiment and hydrogen diffusion through the cell. ${ }^{15}$ As such, an error of \pm 5 can placed on both $\Delta H_{\mathrm{des}}$ and $\Delta S_{\mathrm{des}}$. The reported values will use the result from method 1 due to the improved $R^{2}$ factor. Therefore, $\Delta H_{\text {des }}=$ $106 \pm 5 \mathrm{~kJ} \mathrm{~mol}^{-1} \mathrm{H}_{2}$ and $\Delta S_{\mathrm{des}}=143 \pm 5 \mathrm{~J} \mathrm{~K}^{-1} \mathrm{~mol}^{-1} \mathrm{H}_{2}$.

To put these values into context, for pure $\mathrm{NaH}, \Delta H_{\text {des }}=$ $117 \mathrm{~kJ} \mathrm{~mol}^{-1} \mathrm{H}_{2}$, and $\Delta S_{\text {des }}=167 \mathrm{~J} \mathrm{~K}^{-1} \mathrm{~mol}^{-1} \mathrm{H}_{2} \cdot{ }^{31} \mathrm{~A}$ decrease in $\Delta H_{\text {des }}$ and $\Delta S_{\text {des }}$ in $\mathrm{NaH}_{0.5} \mathrm{~F}_{0.5}$ of $\sim 11 \mathrm{~kJ} \mathrm{~mol}^{-1} \mathrm{H}_{2}$ of $\sim 24 \mathrm{~J} \mathrm{~K}^{-1}$ $\mathrm{mol}^{-1} \mathrm{H}_{2}$ respectively denotes that the equilibrium pressure at which decomposition occurs is significantly lower than that of $\mathrm{NaH}$. Subsequently, the temperature of decomposition of $\mathrm{NaH}_{0.5} \mathrm{~F}_{0.5}$ can be increased without significantly increasing the pressure requirements. For CSP applications this is ideal and also in terms of the aim of this study. As mentioned in the introduction, an ideal operating temperature for these systems is between 550 and $800{ }^{\circ} \mathrm{C},{ }^{6,7,9}$ while reduction in operating pressure at these temperatures will also significantly reduce infrastructure costs and, in turn, safety concerns.

Utilising the numerical fits of the PCI data and the derived van't Hoff plots (Fig. S4†), the variation in desorption enthalpy and entropy as a function of hydrogen content can be established (Fig. S5†). During decomposition, $\Delta H_{\text {des }}$ appears to increase linearly between -0.3 and $-0.9 \mathrm{wt} \% \mathrm{H}_{2}$ from 106 to $113 \mathrm{~kJ} \mathrm{~mol}^{-1} \mathrm{H}_{2}$. At the same time, $\Delta S_{\text {des }}$ appears to be parabolic in nature, with an increase from $144 \mathrm{~J} \mathrm{~K}^{-1} \mathrm{~mol}^{-1} \mathrm{H}_{2}$ at $-0.3 \mathrm{wt} \%$ $\mathrm{H}_{2}$ until a maximum of $147 \mathrm{~J} \mathrm{~K}^{-1} \mathrm{~mol}^{-1} \mathrm{H}_{2}$ at $-0.7 \mathrm{wt} \% \mathrm{H}_{2}$. This is followed by a decrease to $146 \mathrm{~J} \mathrm{~K}^{-1} \mathrm{~mol}^{-1} \mathrm{H}_{2}$ by $-0.9 \mathrm{wt} \% \mathrm{H}_{2}$. Although this is only a small change in $\Delta H_{\text {des }}$ and $\Delta S_{\text {des }}$, it is still significant and may help to explain the sloping nature of the PCI curve. Often, just prior to decomposition of a material to another material (often with a different crystal structure) a flat equilibrium plateau is observed. In this $\mathrm{NaH}_{x} \mathrm{~F}_{1-x}$ system, the starting material and final product have the same $F m \overline{3} m$ space group. During the decomposition process of $\mathrm{NaH}_{0.5} \mathrm{~F}_{0.5}, \mathrm{H}_{2}$ is gradually desorbed forming a product with a larger $\mathrm{F}$ content but with the same structure; $\mathrm{H}$ and $\mathrm{F}$ share the same $4 b$ atomic site, while $\mathrm{Na}$ is also lost through evaporation. Accordingly, the thermodynamics of decomposition change over the course of the experiment. (a)

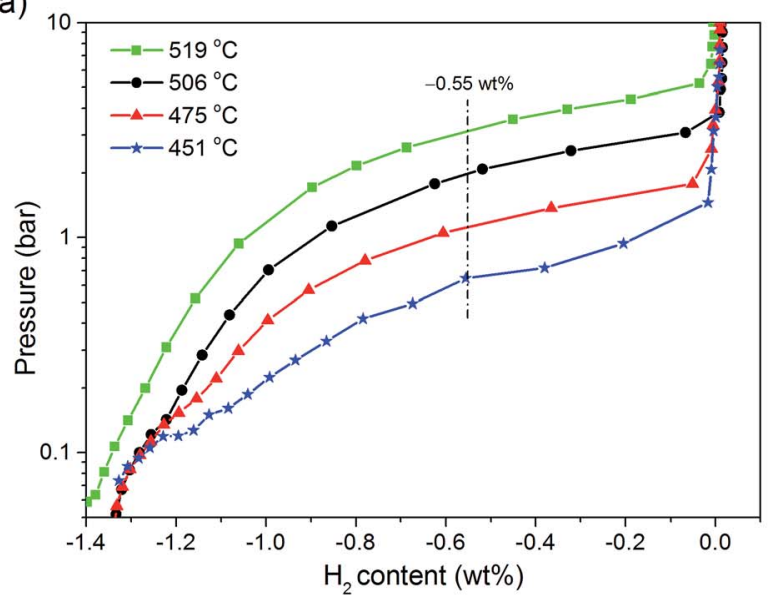

(b)

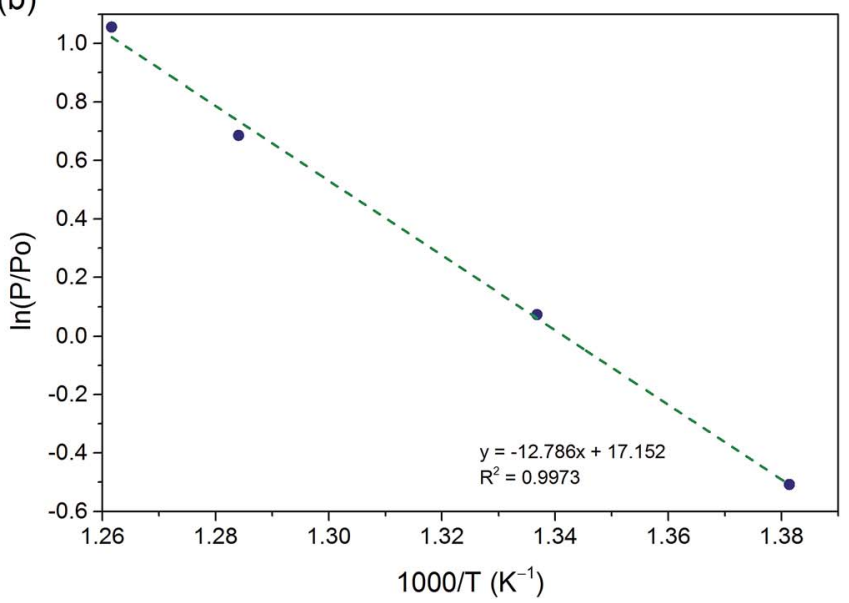

Fig. $3 \mathrm{PCl}$ analysis of $\mathrm{NaH}_{0.5} \mathrm{~F}_{0.5}$ at selected temperatures (a) and van't Hoff plot of respective $\mathrm{H}_{2}$ desorption equilibrium pressures (b). 


\section{In situ XRD studies of $\mathrm{NaH}_{0.5} \mathrm{~F}_{0.5}$}

The in situ XRD data is useful for explaining the process of decomposition (Fig. 4 and S6†). During heating from room temperature to $434{ }^{\circ} \mathrm{C}$, the lattice is observed to expand from 4.7407 (2) to 4.83633 (9) $\AA$ (Fig. 4a and b). At $\sim 430{ }^{\circ} \mathrm{C}$, the shift in peak position to smaller angles, that is associated with thermal expansion, halts and the peaks decrease in intensity and shift to higher angles on further heating. This decrease in the lattice parameters indicates a substantial enrichment of fluorine within in the structure. In fact, during decomposition, the pattern can only be modelled assuming that a range of compositions co-exist. By $485{ }^{\circ} \mathrm{C}$, the composition of the material ranges from $\mathrm{NaH}_{0.48} \mathrm{~F}_{0.52}(2 \mathrm{wt} \%)$ to $\mathrm{NaH}_{0.34} \mathrm{~F}_{0.66}$ (42 $\mathrm{wt} \%$ ) but by $\sim 542{ }^{\circ} \mathrm{C}$ the final composition ranged from $\mathrm{NaH}_{0.26} \mathrm{~F}_{0.74}(3 \mathrm{wt} \%)$ to $\mathrm{NaH}_{0.2} \mathrm{~F}_{0.8}(44 \mathrm{wt} \%)$. Total decomposition was not observed due to obliteration of the quartz capillary. As such, no pure phase of $\mathrm{NaF}$ is detected nor $\mathrm{Na}$ (due to $\mathrm{Na}$ being in its molten state). This result indeed corroborates the variation in thermodynamic properties observed during the PCI experiment as being due to a variation in composition during decomposition.

In a similar in situ XRD experiment, heating of the system was halted at $507.7^{\circ} \mathrm{C}$ and the material allowed to cool at $5{ }^{\circ} \mathrm{C}$ $\min ^{-1}$ under 1 bar $\mathrm{H}_{2}$ in order to replicate the conditions during the TPD experiments (Fig. $4 \mathrm{c}$ and $\mathrm{d}$ and $\mathrm{S} 7 \dagger$ ). The sample continues to decompose as the sample cools to $\sim 470{ }^{\circ} \mathrm{C}$ where the composition of the sample ranges from $\mathrm{NaH}_{0.29} \mathrm{~F}_{0.71}(5 \mathrm{wt} \%)$ to $\mathrm{NaH}_{0.25} \mathrm{~F}_{0.75}(56 \mathrm{wt} \%$ ) (Fig. $\mathrm{S} 7 \dagger)$. By $\sim 442{ }^{\circ} \mathrm{C}$ rehydrogenation of the sample is progressing, with a composition ranging from $\mathrm{NaH}_{0.33} \mathrm{~F}_{0.67}$ (2 wt\%) to $\mathrm{NaH}_{0.27} \mathrm{~F}_{0.73}$ (64 wt\%). Hydrogenation continues over the course of cooling with a final composition of $\mathrm{NaH}_{0.58} \mathrm{~F}_{0.42}(2 \mathrm{wt} \%)$ and $\mathrm{NaH}_{0.3} \mathrm{~F}_{0.7}(51 \mathrm{wt} \%)$ at $98{ }^{\circ} \mathrm{C}$. One perceptible observation is the wide spread of compositions produced during hydrogenation, when in most cases one single phase of a material forms over time. ${ }^{32,33}$ Furthermore, at $98{ }^{\circ} \mathrm{C}$, the final composition of the material contains $2 \mathrm{wt} \%$
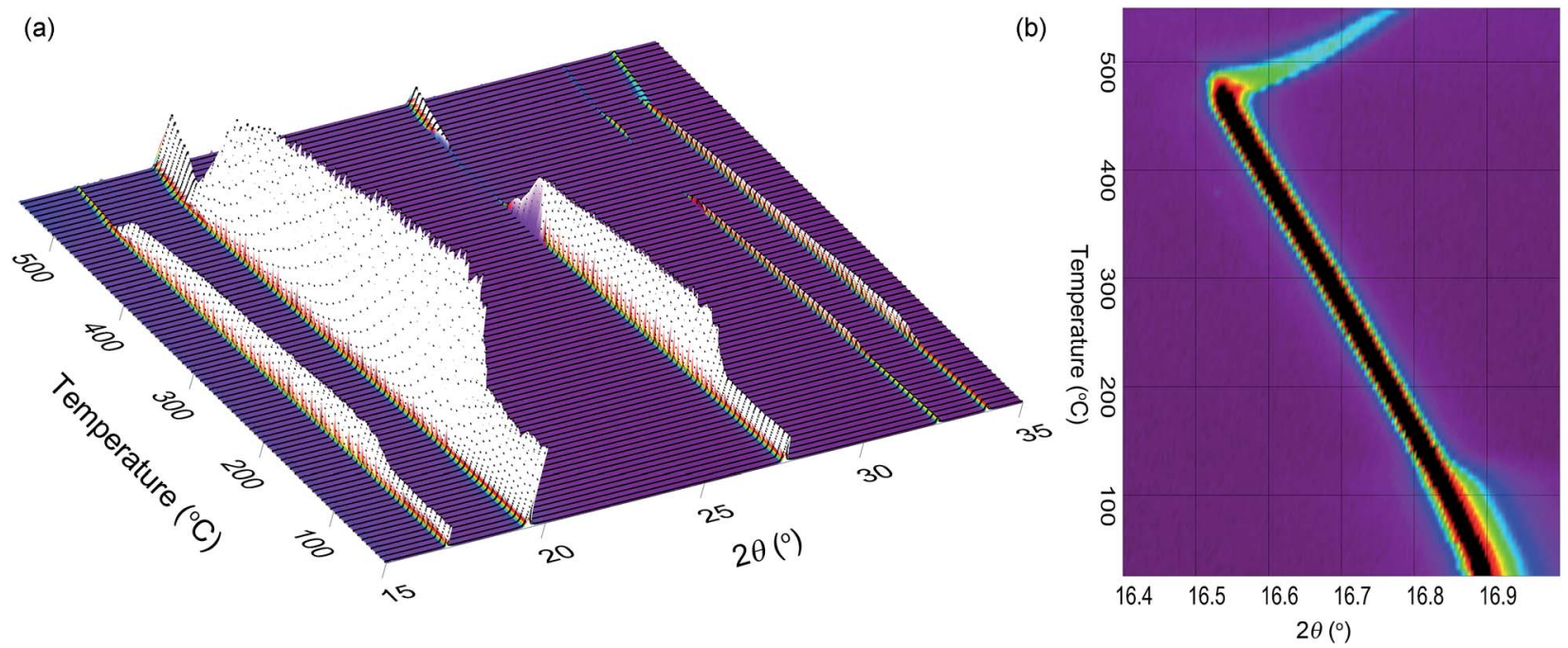

(c)

(d)
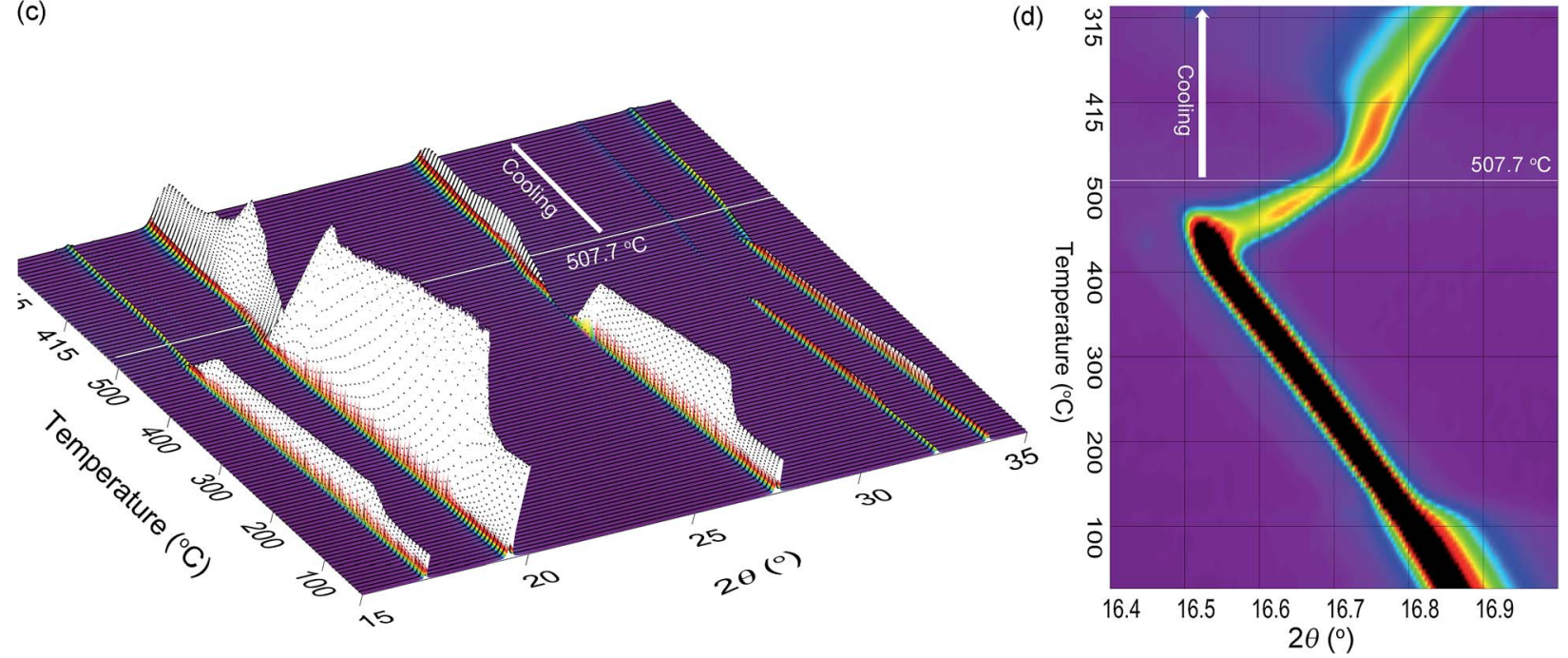

Fig. 4 (a) In situ SR-XRD of $\mathrm{NaH}_{0.5} \mathrm{~F}_{0.5}$ during heating to $542^{\circ} \mathrm{C}$ and (b) an expanded view of the (111) reflection highlighting the changes during desorption of $\mathrm{H}_{2}$. (c) In situ SR-XRD of $\mathrm{NaH}_{0.5} \mathrm{~F}_{0.5}$ during heating to $507.7^{\circ} \mathrm{C}$ and cooling and (d) an expanded view of the (111) reflection highlighting the changes during desorption and absorption of $\mathrm{H}_{2}\left(5^{\circ} \mathrm{C} \mathrm{min}{ }^{-1}, 1\right.$ bar $\left.\mathrm{H}_{2}, \lambda=0.824890 \AA\right)$. 
$\mathrm{NaH}_{0.58} \mathrm{~F}_{0.42}$, which has a greater hydrogen content than the $\mathrm{NaH}_{0.5} \mathrm{~F}_{0.5}$ starting material. This is attributed to the mobility of Na during the decomposition process away from the hot zone which prevents the even formation of $\mathrm{NaH}_{0.5} \mathrm{~F}_{0.5}$. Nevertheless, this experiment illustrates the enhanced reversibility of this system compared to that of pure $\mathrm{NaH}$ and reiterates the results of the TPD experiment.

\section{Cycling studies}

A sample of $\mathrm{NaH}_{0.5} \mathrm{~F}_{0.5}$ was cycled seven times between 475 and $525{ }^{\circ} \mathrm{C}$ (Sieverts apparatus) to explore its extended reversibility and to determine its feasibility for technological applications (Fig. 5a). To ensure that Na did not evaporate during decomposition, the sample was loaded into a thin walled Fe tube..$^{23,24}$ While heating the sample to $475{ }^{\circ} \mathrm{C}$ the initial pressure was set to 10 bar to inhibit decomposition. The pressure was then reduced to 3 bar and the temperature ramped to $525^{\circ} \mathrm{C}$. During the consecutive cycles, no significant decrease in capacity was observed. The material desorbed a maximum of $0.72 \mathrm{wt} \% \mathrm{H}_{2}$ and reabsorbed $0.5 \mathrm{wt} \% \mathrm{H}_{2}$.

The fact that full reversibility was not achieved is due to the sloping equilibrium plateau pressure determined during the PCI experiments (Fig. 3a). An initial pressure of 3 bar $\mathrm{H}_{2}$ was used to ensure that the $\mathrm{H}_{2}$ pressure was above the equilibrium pressure at $475{ }^{\circ} \mathrm{C}$ and hence guarantee absorption. At $525{ }^{\circ} \mathrm{C}$ the equilibrium pressure should have reached $\sim 4.2$ bar (for $0.9 \mathrm{wt} \%$ desorption) although this system did not pass $3.5 \mathrm{bar}$ upon desorption, but absorption at $475{ }^{\circ} \mathrm{C}$ would also cease at 1.5 bar (for $0.9 \mathrm{wt} \%$ absorption). As such, as the $\mathrm{H}_{2}$ leaked through the reactor walls, the drop in pressure inhibited full absorption of $\mathrm{H}_{2}$ into the material to the full extent it exhibited on the first two cycles.

This result determined that the sample is reversible and most importantly that the Fe tube inhibited the evaporation of Na. That being said, SR-XRD analysis of the final sample in the hydrogenated state indicated that total rehydrogenation had not occurred (Fig. 5b). Profile analysis of the pattern allowed for the determination of the lattice parameters of the contained phases and hence the composition of the material. Using eqn (1), the composition is determined to be a mixture of $\mathrm{NaH}_{0.21} \mathrm{~F}_{0.79}$ (10 wt\%), $\mathrm{NaH}_{0.33} \mathrm{~F}_{0.67}$ (45 wt\%), $\mathrm{NaH}_{0.36} \mathrm{~F}_{0.64}$ (24 wt\%). In addition, $\mathrm{NaHF}_{2}$ was not observed in the powder product as it is thermodynamically unstable in the presence of $\mathrm{Na}$ and/or $\mathrm{NaH} .^{34}$

Although the time allotted for the final hydrogen absorption step was not as prolonged as the six previous hydrogenation steps, $\mathrm{Na}$ is deemed to have evaporated from the sample as no $\mathrm{Na}$ was determined by XRD, as such better crimping of the sample is required, especially if a technological application is to be found.

\section{Technological application of $\mathrm{NaH}_{x} \mathrm{~F}_{1-x}$}

The substantial improvement in the reversible hydrogenation capacity of $\mathrm{NaH}$ by the formation of $\mathrm{NaH}_{x} \mathrm{~F}_{1-x}$ solid-state has been undertaken to make $\mathrm{NaH}$ remotely reversible. ${ }^{8}$ Addition of $\mathrm{NaF}$ increases the temperature of decomposition to $440{ }^{\circ} \mathrm{C}(\max$ $\mathrm{H}_{2}$ release) compared to $408^{\circ} \mathrm{C}$ for pure $\mathrm{NaH}$. At the same time, $\Delta H_{\mathrm{des}}$ and $\Delta S_{\mathrm{des}}$ of $106 \pm 5 \mathrm{~kJ} \mathrm{~mol}^{-1} \mathrm{H}_{2}$ and $143 \pm 5 \mathrm{~J} \mathrm{~K}^{-1} \mathrm{~mol}^{-1}$ $\mathrm{H}_{2}$ for $\mathrm{NaH}_{0.5} \mathrm{~F}_{0.5}$ is reduced compared to pure NaH. Although a reduction in the $\Delta H_{\text {des }}$ compared to $\mathrm{NaH}$ is not ideal, $\Delta S_{\text {des }}$ decreases substantially more with $\mathrm{F}$ substitution than does the $\Delta H_{\text {des }}$. Hence the $\mathrm{H}_{2}$ equilibrium pressure is substantially decreased with only a minor decrease in the enthalpy. Overall, these factors bode well for the integration of these materials into thermal energy applications.

In comparison to other materials considered for thermal energy applications, $\mathrm{NaH}_{0.5} \mathrm{~F}_{0.5}$ is especially competitive in regards to the operating temperature (Table 2). For instance, in CSP applications an ideal operating temperature range is between 550 and $800{ }^{\circ} \mathrm{C} .6^{6,79}$ As such, the operational properties of $\mathrm{NaH}_{0.5} \mathrm{~F}_{0.5}$ lead to a greater plant efficiency. The higher reaction enthalpy of $\mathrm{NaH}_{0.5} \mathrm{~F}_{0.5}$ compared to $\mathrm{MgH}_{2}$, for instance, decreases the overall hydrogen mass required to generate an equivalent electrical output and therefore decreases the heat transfer area of the systems. Furthermore, the lower hydrogen mass requirement decreases the quantity of the low (a)

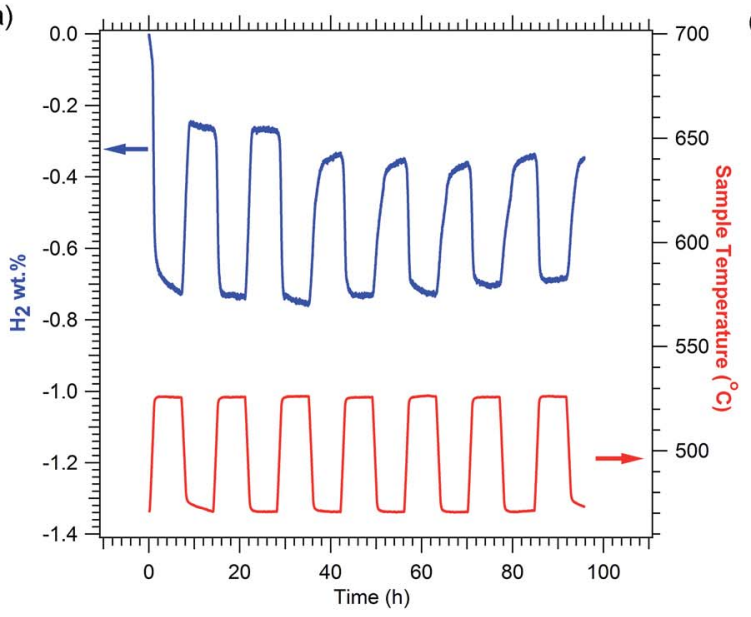

(b)

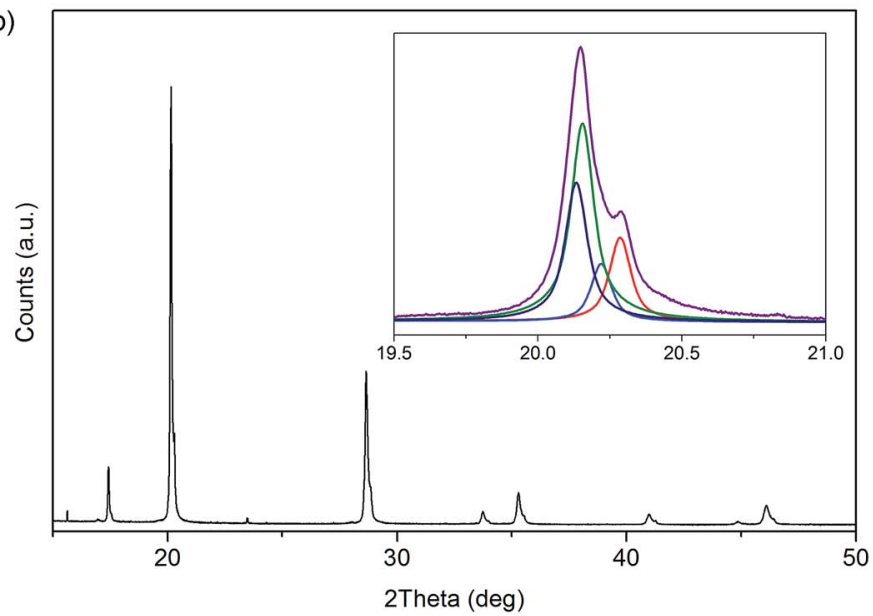

Fig. 5 Cycling of $\mathrm{NaH}_{0.5} \mathrm{~F}_{0.5}$ between 470 and $520^{\circ} \mathrm{C}$ (a) and SR-XRD characterisation of the final product (b). $\lambda=0.824890 \AA$. 
Table 2 Properties of selected metal hydrides and calculated operating temperatures between 1 and 150 bar $^{a}$

\begin{tabular}{|c|c|c|c|c|}
\hline Material & $\begin{array}{l}\text { Theoretical } \mathrm{H}_{2} \text { capacity } \\
\text { (wt } \% \text { ) }\end{array}$ & $\begin{array}{l}\Delta H_{\mathrm{des}} \\
\left(\mathrm{kJ} \mathrm{mol}^{-1} \mathrm{H}_{2}\right)\end{array}$ & $\begin{array}{l}\text { Operating range } \\
\left({ }^{\circ} \mathrm{C}\right)\end{array}$ & $\begin{array}{l}\text { Theoretical thermal } \\
\text { storage capacity }\left(\mathrm{kJ} \mathrm{kg}^{-1}\right)\end{array}$ \\
\hline $\mathrm{NaH}_{0.5} \mathrm{~F}_{0.5}$ & 1.53 & 106 & $470-775$ & 803 \\
\hline $\mathrm{NaMgH}_{3}-1$ step & 4.01 & 86.6 (ref. 16) & $382-683$ & 1721 \\
\hline $\mathrm{NaH}$ & 4.20 & 116.8 (ref. 31) & $426-659$ & 2434 \\
\hline $\mathrm{NaBH}_{4}$ & 10.67 & 100.4 (ref. 34) & $511-890$ & 5709 \\
\hline
\end{tabular}

${ }^{a}$ Pressures noted correspond to calculated fugacities (pressure $=$ fugacity/compressibility of $\mathrm{H}_{2}$ ). ${ }^{b}$ Maximum temperature unachievable due to sintering. ${ }^{36}$

temperature hydride ${ }^{\mathbf{8 - 1 0 , 1 5 , 1 7 , 3 7}}$ which is the most expensive component of the coupled system. ${ }^{37}$ These factors counteract the decreased theoretical hydrogen capacity for $\mathrm{NaH}_{0.5} \mathrm{~F}_{0.5}$, which is lower than the majority of the materials listed in Table 2. One major advantage of $\mathrm{NaH}_{0.5} \mathrm{~F}_{0.5}$ is the cost of the materials. It is estimated that $\mathrm{NaH}$ costs US\$ $4.8 \mathrm{per} \mathrm{kg}^{-1}$, while NaF costs $\sim$ US\$ 1.2 per $\mathrm{kg}^{-1} .^{38}$ This translates to a cost of $\sim$ US\$ 10 per $\mathrm{kW} \mathrm{h}$ th for $\mathrm{NaH}_{0.5} \mathrm{~F}_{0.5}$, while NaH would cost $\sim$ US\$ 12 per $\mathrm{kW} \mathrm{h}$ th , a decrease of $17 \%$. For a CSP plant which would require thousands of tons of material to operate, this is a vast saving.

Other than the relatively low hydrogen capacity of $\mathrm{NaH}_{0.5} \mathrm{~F}_{0.5}$, the major drawback is the sloping plateau observed from the PCI measurements (Fig. 3). This causes the operational pressures for which full reversibility is achievable to become wider as lower pressures are required for full dehydrogenation, while higher pressures are required for full hydrogenation. A workaround for this situation is to increase the volume of the reactor and extend the temperature differential between desorption and absorption.

Another disadvantage is the distillation of Na upon decomposition. As decomposition occurs, the $\mathrm{Na}$ vapour will agglomerate in the cooler parts of the reactor bed. As such, the reversibility of the material decreases as segregation occurs. This will ultimately lead to NaF rich areas of material. Means to prevent $\mathrm{Na}$ loss from the reactor bed have been identified (such as Fe membranes that are permeable to $\mathrm{H}_{2}$ at high temperatures but not $\mathrm{Na}$ vapour) but this will require engineering of this solution on a large scale suitable for CSP application. To prevent $\mathrm{NaF}$ segregation and increase $\mathrm{H}$ capacity, the use of lower fractions of NaF may be beneficial. This is to be developed in a future publication. The assessment of long term cycling of these materials will also determine the overall effects of these detrimental properties.

\section{Conclusions}

The solid-state solutions of $\mathrm{NaH}_{x} \mathrm{~F}_{1-x}(x=1,0.95,0.85,0.5)$ have been investigated to determine their potential for thermal energy applications. Thermal desorption measurements have determined that the temperature for maximum hydrogen desorption of $\mathrm{NaH}_{0.5} \mathrm{~F}_{0.5}$ is $443{ }^{\circ} \mathrm{C}$, releasing $1.3 \mathrm{wt} \% \mathrm{H}_{2}$ (theoretical: $1.5 \mathrm{wt} \% \mathrm{H}_{2}$ ), while pure $\mathrm{NaH}$ decomposes at $408{ }^{\circ} \mathrm{C}$. PCI measurements indicate a sloping single-step hydrogen desorption curve with a plateau mid-point enthalpy of $106 \pm 5 \mathrm{~kJ} \mathrm{~mol}^{-1}$ $\mathrm{H}_{2}$ and an entropy of desorption of $143 \pm 5 \mathrm{~J} \mathrm{~K}^{-1} \mathrm{~mol}^{-1} \mathrm{H}_{2}$. These values are decreased in comparison to $117 \mathrm{~kJ} \mathrm{~mol}^{-1} \mathrm{H}_{2}$ and $167 \mathrm{~J} \mathrm{~K}^{-1} \mathrm{~mol}^{-1} \mathrm{H}_{2}$, respectively, for pure NaH. While the fluorine substitution actually leads to a decrease in the stability (enthalpy) compared to pure $\mathrm{NaH}$, it has a larger depressing effect on the entropy that leads to reduced hydrogen equilibrium pressures. The solid state solutions of $\mathrm{NaH}_{x} \mathrm{~F}_{1-x}$ are reversible compared to pure $\mathrm{NaH}$ and are shown to absorb hydrogen below 1 bar $\mathrm{H}_{2}$, above $350{ }^{\circ} \mathrm{C}$. Cycling of $\mathrm{NaH}_{0.5} \mathrm{~F}_{0.5}$ has been investigated over seven cycles and although the theoretical capacity is not met, capacity is not greatly reduced. Despite the relatively modest thermal storage capacity compared to other metal hydrides, the high enthalpy and operating temperatures of $\mathrm{NaH}_{x} \mathrm{~F}_{1-x}$ means that substantially less hydrogen is required for generating electric power compared to other metal hydrides for solar thermal storage. As such, these low cost ( $\sim$ US\$ 10 per $\mathrm{kW} \mathrm{h}$ th for $\mathrm{NaH}_{0.5} \mathrm{~F}_{0.5}$ ) materials hold great potential as thermal energy storage materials for concentrating solar thermal power applications.

\section{Acknowledgements}

The authors acknowledge the financial support of the Australian Research Council (ARC) for ARC Linkage grant LP120101848, LP150100730 and ARC LIEF grants LE0989180 and LE0775551, which enabled the XRD and gas sorption studies to be done. We would like to thank the project teams at the Australian Synchrotron Powder Diffraction Beam Line.

\section{Notes and references}

1 Worldometers, Worldometers, http://www.worldometers.info/ world-population/, accessed January 19, 2016.

2 M. Fellet, C. E. Buckley, M. Paskevicius and D. A. Sheppard, MRS Bull., 2013, 38, 1012-1013.

3 D. A. Sheppard, T. D. Humphries and C. E. Buckley, Mater. Today, 2015, 18, 414-415.

4 D. N. Harries, M. Paskevicius, D. A. Sheppard, T. Price and C. E. Buckley, Proc. IEEE, 2012, 100, 539-549.

5 E. S. Freeman, J. Phys. Chem., 1956, 60, 1487-1493. 
6 US Department of Energy, D.O.E. ARPA-E High Energy Advanced Thermal Storage - DE-FOA-0000471, https://arpae-foa.energy.gov/FileContent.aspx?FileID=79a5de09-8bfd4590-9cb4-e42578248d90, accessed March 21, 2016.

7 SunShot Vision Study, Chapter 5: Concentrating Solar Power: Technologies, Cost, and Performance, US Department of Energy, US Department of Energy, 2012.

8 D. A. Sheppard, T. D. Humphries and C. E. Buckley, Appl. Phys. A, 2016, 122, 406.

9 D. A. Sheppard, M. Paskevicius, T. D. Humphries, M. Felderhoff, G. Capurso, J. Bellosta von Colbe, M. Dornheim, T. Klassen, P. A. Ward, J. A. Teprovich, C. Corgnale, R. Zidan, D. M. Grant and C. E. Buckley, Appl. Phys. A, 2016, 122, 395.

10 P. A. Ward, C. Corgnale, J. A. Teprovich, T. Motyka, B. Hardy, D. A. Sheppard, C. E. Buckley and R. Zidan, Appl. Phys. A, 2016, 122, 462.

11 Q. Lai, M. Paskevicius, D. A. Sheppard, C. E. Buckley, A. W. Thornton, M. R. Hill, Q. Gu, J. Mao, Z. Huang, H. K. Liu, Z. Guo, A. Banerjee, S. Chakraborty, R. Ahuja and K.-F. Aguey-Zinsou, ChemSusChem, 2015, 8, 2789-2825.

12 M. Paskevicius, D. A. Sheppard, K. Williamson and C. E. Buckley, Energy, 2015, 88, 469-477.

13 M. Felderhoff, R. Urbanczyk and S. Peil, Green, 2013, 3, 113123.

14 C. E. Messer, J. Solid State Chem., 1970, 2, 144-155.

15 D. A. Sheppard, C. Corgnale, B. Hardy, T. Motyka, R. Zidan, M. Paskevicius and C. E. Buckley, RSC Adv., 2014, 4, 2655226562.

16 D. A. Sheppard, M. Paskevicius and C. E. Buckley, Chem. Mater., 2011, 23, 4298-4300.

17 P. A. Ward, C. Corgnale, J. A. Teprovich, T. Motyka, B. Hardy, B. Peters and R. Zidan, J. Alloys Compd., 2015, 645, S374S378.

18 E. R. Pinatel, M. Corno, P. Ugliengo and M. Baricco, J. Alloys Compd., 2014, 615(1), S706-S710.

19 K. S. Wallwork, B. J. Kennedy and D. Wang, Synchrotron Radiation Instrumentation: Ninth International Conference on Synchrotron Radiation Instrumentation, 2007.

20 B. Schmitt, C. Brönnimann, E. Eikenberry, F. Gozzo, C. Hörmann, R. Horisberger and B. Patterson, Nucl. Instrum. Methods Phys. Res., Sect. A, 2003, 501, 267-272.
21 R. A. Young and R. A. Young, The Rietveld Method, Oxford UniversityPress, 1995.

22 M. Paskevicius, D. A. Sheppard and C. E. Buckley, J. Am. Chem. Soc., 2010, 132, 5077-5083.

23 D. M. Banus, J. J. McSharry and E. A. Sullivan, J. Am. Chem. Soc., 1955, 77, 2007-2010.

24 W. Klostermeier and E. U. Franck, Ber. Bunsen-Ges. Phys. Chem., 1982, 86, 606-612.

25 Y. Shirako, Y. G. Shi, A. Aimi, D. Mori, H. Kojitani, K. Yamaura, Y. Inaguma and M. Akaogi, J. Solid State Chem., 2012, 191, 167-174.

26 C. G. Shull, E. O. Wollan, G. A. Morton and W. L. Davidson, Phys. Rev., 1948, 73, 842-847.

27 A. R. Denton and N. W. Ashcroft, Phys. Rev. A, 1991, 43, 31613164.

28 D. B. Ravnsbæk, L. H. Rude and T. R. Jensen, J. Solid State Chem., 2011, 184, 1858-1866.

29 R. Cvetanovic and Y. Amenomiya, Adv. Catal., 1967, 17, 103149.

30 T. D. Humphries, G. N. Kalantzopoulos, I. Llamas-Jansa, J. E. Olsen and B. C. Hauback, J. Phys. Chem. C, 2013, 117, 6060-6065.

31 F. D. Manchester and A. San-Martin, Phase Diagrams of Binary Hydrogen Alloys, ASM International, Ohio, 2000.

32 T. D. Humphries, M. B. Ley, C. Frommen, K. T. Munroe, T. R. Jensen and B. C. Hauback, J. Mater. Chem. A, 2015, 3, 691-698.

33 T. D. Humphries, J. W. Makepeace, S. Hino, W. I. F. David and B. C. Hauback, J. Mater. Chem. A, 2014, 2, 16594-16600.

34 Outukumpu, Chemistry Software, Houston, 9th edn, 2006.

35 A. Reiser, B. Bogdanovic and K. Schlichte, Int. J. Hydrogen Energy, 2000, 25, 425-430.

36 B. Bogdanović, H. Hofmann, A. Neuy, A. Reiser, K. Schlichte, B. Spliethoff and S. Wessel, J. Alloys Compd., 1999, 292, 5771.

37 C. Corgnale, B. Hardy, T. Motyka, R. Zidan, J. Teprovich and B. Peters, Renewable Sustainable Energy Rev., 2014, 38, 821833.

38 Metal Prices.com, http://www.metalprices.com/metal/ magnesium/magnesium-99-9-usa, accessed 15 June 2016. 